\title{
Chrysogenamide A from an Endophytic Fungus Associated with Cistanche deserticola and Its Neuroprotective Effect on SH-SY5Y Cells
}

\author{
Zhenjian Lin, Jiangni Wen, Tianjiao Zhu, Yuchun Fang, Qianqun Gu, Weiming Zhu
}

Received: November 12, 2007 / Accepted: January 15, 2008

(C) Japan Antibiotics Research Association

\begin{abstract}
Chrysogenamide A (1), a new member of the macfortine group of alkaloids, along with four known compounds (2 $\sim \mathbf{5})$ were identified from Penicillium chrysogenum No. 005, an endophytic fungus associated with Cistanche deserticola Y. C. Ma. The new structure was elucidated on the basis of comprehensive spectral analysis. 1 exhibited a neurocyte protection effect against oxidative stress-induced cell death in SH-SY5Y cells.
\end{abstract}

Keywords chrysogenamide A; endophyte; Penicillium chrysogenum; Cistanche deserticola; neurocyte protection; marcfortine alkaloids

\section{Introduction}

Cistanche deserticola (Y. C. Ma) is a parasitic plant native to the northwest of China. The stem of this plant is an important traditional Chinese medicine and is used for the treatment of kidney deficiency and neurasthenia ("The Chinese Medicine Dictionary", 1977). Phenylthanoid glycosides from $C$. deserticola have been reported to have activities in preventing and treating cranial nerve diseases and scavenging free radicals $[1,2]$. Based on the fact that endophytic fungi can produce new medicinal components and the same/similar ones as those from the host plants, searching for new active compounds from endophytic fungi

Q. Gu, W. Zhu (Corresponding author), Z. Lin, J. Wen, T. Zhu, Y. Fang: Key Laboratory of Marine Drugs, Chinese Ministry of Education; School of Medicine and Pharmacy, Ocean University of China, Qingdao 266003, P.R. China,

E-mail: guqianq@ouc.edu.cn and weimingzhu@ouc.edu.cn of important medicinal plants shows value for the development of new medicinal resources. In the course of our search for new neuroprotective compounds from endophytic fungi from $C$. deserticola collected from Inner Mongolia in northwest China, three active strains were screened using SH-SY5Y cells. Among them, the culture broth of a fungus No. 005, authenticated as Penicillium chrysogenum, showed a significant neurocyte protection effect against oxidative stress-induced cell death in SH-SY5Y cells. Studies on the active constituents of this strain led to the isolation of chrysogenamide A (1) (Fig. 1) through a bioassay-guided isolation procedure. In addition, four known compounds were isolated and identified as circumdatin G (2) [3], 2-[(2-hydroxypropionyl) amino] benzamide (3) [4], 2',3'-dihydrosorbicillin (4) [5] and (9Z,12Z)-2,3-dihydroxypropyl octadeca-9,12-dienoate (5) [6], by comparison of their spectroscopic data with literature data. Here, we report on the isolation, identification and neuroprotective effect of chrysogenamide A.

\section{Materials and Methods}

\section{Fungal Material}

A sample of Penicillium chrysogenum No. 005 was isolated from the root of $C$. deserticola collected from Inner Mongolia in northwest China. On potato dextrose agar the macroscopic appearance was of spreading, smooth, velvety, blue-green colonies sometimes overgrown with light hyphae; the surface of the colonies often showed numerous light yellow droplets; reverse yellow. A GenBank search with the 18S ribosomal DNA gene sequence of No. 005 (1676 nucleotides; Gen-Bank accession number 


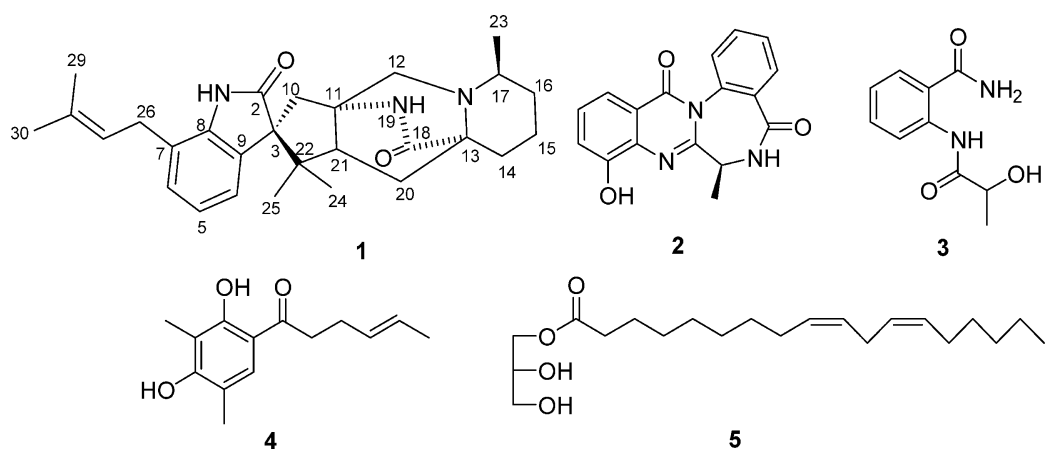

Fig. 1 Structures of chrysogenamide A (1), circumdatin G (2), benzamide (3), 2',3'-dihydrosorbicillin (4), (9Z,12Z)-2,3dihydroxypropyloctadeca-9,12-dienoate (5).

EU203859) was carried out. The results indicate a species of Penicillium chrysogenum as the closest match. On the basis of its macroscopic appearance and $18 \mathrm{~S}$ rDNA gene sequence, No.005 is a strain of Penicillium chrysogenum.

\section{Fermentation and Extraction}

The fungus was grown under static conditions at $24^{\circ} \mathrm{C}$ for 30 days in $351000-\mathrm{ml}$ conical flasks containing a liquid medium ( $300 \mathrm{ml} /$ flask) composed of glucose $(10 \mathrm{~g} /$ liter $)$, maltose ( $20 \mathrm{~g} /$ liter), mannitol ( $20 \mathrm{~g} /$ liter $)$, monosodium glutamate (10 g/liter), $\mathrm{KH}_{2} \mathrm{PO}_{4}(0.5 \mathrm{~g} /$ liter $), \mathrm{MgSO}_{4} \cdot 7 \mathrm{H}_{2} \mathrm{O}$ $(0.3 \mathrm{~g} /$ liter $)$, corn steep liquor $(1.0 \mathrm{~g} /$ liter $)$ and yeast extract $(3.0 \mathrm{~g} /$ liter $)$ and seawater after adjusting its $\mathrm{pH}$ to 7.0 . The fermented whole broth (10.5 liters) was extracted three times with EtOAc to give an EtOAc soln, which was concentrated under reduced pressure to give a crude extract $(9.5 \mathrm{~g})$.

\section{Purification}

The crude extract (9.5 g) was separated into 15 fractions on a silica gel column using a step gradient elution of petroleum ether $/ \mathrm{Me}_{2} \mathrm{CO}$. The fraction 2, eluted with $8: 2$ petroleum ether $/ \mathrm{Me}_{2} \mathrm{CO}$, was recrystallized from $\mathrm{MeOH}$, yielding 3 as colorless needles $(8.0 \mathrm{mg})$. The fraction 3 $(19.0 \mathrm{mg})$, eluted with $7: 3$ petroleum ether $/ \mathrm{Me}_{2} \mathrm{CO}$, was further separated by reversed-phase column (RP18, $40 \sim 60 \mu \mathrm{m}$, Merck; $\left.\mathrm{MeOH}-\mathrm{H}_{2} \mathrm{O}=3: 2 \rightarrow 4: 1 \rightarrow \mathrm{MeOH}\right)$ to afford fr. $3 \sim 7(8.0 \mathrm{mg})$, which was purified by extensive PHPLC (60\% MeOH containing 0.1\% TFA, $4.0 \mathrm{ml} /$ minute) to give $4(2.0 \mathrm{mg})$. The fraction $4(26.0 \mathrm{mg})$, eluted with $6: 4$ petroleum ether $/ \mathrm{Me}_{2} \mathrm{CO}$, was further separated by reversed-phase column (RP18, 40 60 $\mu \mathrm{m}$, Merck; $\left.\mathrm{MeOH}-\mathrm{H}_{2} \mathrm{O}=3: 2 \rightarrow 4: 1 \rightarrow \mathrm{MeOH}\right)$ to afford fr. $4-3$ $(5.4 \mathrm{mg})$ and fr. $4-9(7.6 \mathrm{mg})$. Then, the fr. 4-3 was separated by extensive PHPLC [YMC-pack ODS (A), $10 \times 250 \mathrm{~mm}, \quad 5 \mu \mathrm{m}, \quad 4.0 \mathrm{ml} /$ minute $] \quad(60 \% \mathrm{MeOH}$, $4.0 \mathrm{ml} /$ minute) to yield $2(1.0 \mathrm{mg})$, and the fr. $4-9$ was separated by extensive PHPLC $(80 \% \quad \mathrm{MeOH}$, $4.0 \mathrm{ml} /$ minute $)$ to yield $\mathbf{1}(4.0 \mathrm{mg})$ and $\mathbf{5}(2.6 \mathrm{mg})$.

1: obtained as pale yellow solid; $[\alpha]_{\mathrm{D}}^{25}+24.5^{\circ}(c 0.155$, $\mathrm{MeOH}) ; \mathrm{UV}(\mathrm{MeOH}) \lambda_{\max } 208,251 \mathrm{~nm} ; \mathrm{CD}(\mathrm{MeOH})$ (see Fig. 4); IR (KBr) $v_{\max } 3433,3200,3076,2928,2862,1677$, 1440, 1370, 1324, 1188, $1029 \mathrm{~cm}^{-1}$; ${ }^{1} \mathrm{H}-$ and ${ }^{13} \mathrm{C}-\mathrm{NMR}$ (see Table 1); HRESI-MS $m / z 448.2951[\mathrm{M}+\mathrm{H}]^{+}$(calcd for $\left.\mathrm{C}_{28} \mathrm{H}_{38} \mathrm{~N}_{3} \mathrm{O}_{2}, 448.2964\right)$.

\section{DPPH Radical Scavenging Effect}

A MeOH soln $(160 \mu \mathrm{l})$ of varying sample concentrations $(1.0 \mathrm{mg} / \mathrm{ml} \sim 0.0001 \mathrm{mg} / \mathrm{ml})$ was added to $40 \mu 1 \mathrm{DPPH}(1,1-$ diphenyl-2-picrylhydrazyl; Sigma) $\mathrm{MeOH}$ soln (1.5× $\left.10^{-4} \mathrm{M}\right)$. After mixing gently and leaving for 30 minutes at room temperature, the optical density was measured at $520 \mathrm{~nm}$ using a spectrophotometer. The antioxidant activity of each sample was expressed in terms of $\mathrm{IC}_{50}(\mu \mathrm{g} / \mathrm{ml}$ or $\mu \mathrm{M}$ required to inhibit DPPH radical formation by $50 \%$ ) and calculated from the log-dose inhibition curve.

\section{Cell Culture and Drug Treatment}

Human neuroblastoma SH-SY5Y cells were cultured in DMEM medium and maintained at $37^{\circ} \mathrm{C}$ in a humidified atmosphere with $5.0 \% \mathrm{CO}_{2}$. These cell suspensions $(180 \mu \mathrm{l})$ at a density of $5 \times 10^{4} \mathrm{cell} \mathrm{ml}^{-1}$ were plated in 96 well microtiter plates and incubated for 24 hours at the above condition. Chrysogenamide A solution $(2.0 \mu \mathrm{l}$ in DMSO) at different concentrations was added to each well except the control and model groups and further incubated for 1 hour in the same conditions. $\mathrm{H}_{2} \mathrm{O}_{2}$ (Sigma Chemical Co., MO, USA) was added to induce apoptosis in $\mathrm{SH}$ SY5Y cells at a final concentration of $200 \mu \mathrm{M}$ for 24 hours. Cell viability was determined using an MTT assay. MTT dissolved in phosphate buffered saline was added at the end of incubation to a final concentration of $5.0 \mathrm{mg} / \mathrm{ml}$ (PBS), and then incubated at $37^{\circ} \mathrm{C}$ for 4 hours. Discarding the supernatant, the resultant formazan product was dissolved 
Table $1{ }^{1} \mathrm{H}$ - and ${ }^{13} \mathrm{C}-\mathrm{NMR}$ data $(600$ and $150 \mathrm{MHz})$ of chrysogenamide $A(\mathbf{1})$ in DMSO- $d_{6}$

\begin{tabular}{|c|c|c|}
\hline No. & ${ }^{1} \mathrm{H}(\mathrm{J}=\mathrm{Hz})$ & ${ }^{13} \mathrm{C}$ \\
\hline $1-\mathrm{NH}$ & $10.36 \mathrm{~s}$ & - \\
\hline 2 & - & 183.1, qC \\
\hline 3 & - & $62.3, q C$ \\
\hline 4 & $7.18 \mathrm{~d}(7.3)$ & 123.6, CH \\
\hline 5 & $6.90 \mathrm{dd}(7.3,7.3)$ & $120.8, \mathrm{CH}$ \\
\hline 6 & $6.94 \mathrm{~d}(7.3)$ & 127.7, CH \\
\hline 7 & - & 122.1, qC \\
\hline 8 & - & 140.4, qC \\
\hline 9 & - & 129.9, qC \\
\hline $10 a$ & $2.20 \mathrm{~m}^{\mathrm{a}}$ & 39.9, $\mathrm{CH}_{2}$ \\
\hline $10 b$ & $2.09 \mathrm{~m}^{\mathrm{a}}$ & \\
\hline 11 & - & $60.4 \mathrm{qC}$ \\
\hline $12 a$ & $3.32 \mathrm{~d}(8.7)$ & $64.9, \mathrm{CH}_{2}$ \\
\hline $12 b$ & $2.22 \mathrm{~m}^{\mathrm{a}}$ & \\
\hline 13 & - & $58.7, \mathrm{qC}$ \\
\hline $14 a$ & $1.44 \mathrm{~m}^{\mathrm{a}}$ & 20.7, $\mathrm{CH}_{2}$ \\
\hline $14 b$ & $1.15 \mathrm{~m}^{\mathrm{a}}$ & \\
\hline $15 a$ & 2.08 m & 31.8, $\mathrm{CH}_{2}$ \\
\hline $15 b$ & $10.36 \mathrm{~s}$ & \\
\hline $16 a$ & $1.52 \mathrm{~m}$ & 34.3, $\mathrm{CH}_{2}$ \\
\hline $16 b$ & $1.08 \mathrm{~m}$ & \\
\hline 17 & $2.02 \mathrm{~m}$ & 58.7, $\mathrm{CH}$ \\
\hline 18 & - & 172.3, qC \\
\hline 19-NH & $8.29 \mathrm{~s}$ & \\
\hline $20 a$ & $1.63 \mathrm{dd}(10.1,13.2)$ & $35.2, \mathrm{CH}_{2}$ \\
\hline $20 b$ & $1.37 \mathrm{dd}(7.8,13.2)$ & \\
\hline 21 & $2.89 \mathrm{dd}(9.1,9.2)$ & 46.1, CH \\
\hline 22 & - & $46.5, \mathrm{qC}$ \\
\hline 23 & $0.98 d(6.0)$ & $21.5, \mathrm{CH}_{3}$ \\
\hline 24 & $0.62 \mathrm{~s}$ & 22.7, $\mathrm{CH}_{3}$ \\
\hline 25 & $0.87 \mathrm{~s}$ & $20.1, \mathrm{CH}_{3}$ \\
\hline 26 & $3.23 \mathrm{~m}$ & $28.4, \mathrm{CH}_{2}$ \\
\hline 27 & $5.27 \mathrm{dd}(7.3,7.3)$ & 121.9, $\mathrm{CH}$ \\
\hline 28 & - & 132.3, qC \\
\hline 29 & $1.70 \mathrm{~s}$ & $25.5, \mathrm{CH}_{3}$ \\
\hline 30 & $1.67 \mathrm{~s}$ & 17.7, $\mathrm{CH}_{3}$ \\
\hline
\end{tabular}

${ }^{a}$ Signals overlapping. qC; quarternaly carbon.

with $200 \mu \mathrm{l}$ DMSO and detected at $570 \mathrm{~nm}$.

\section{Results and Discussion}

1 was obtained as pale yellow solid. The molecular formula was determined as $\mathrm{C}_{28} \mathrm{H}_{37} \mathrm{~N}_{3} \mathrm{O}_{2}$ by HRESI-MS (observed $[\mathrm{M}+\mathrm{H}]^{+}$at $m / z$ 448.2951, calcd $[\mathrm{M}+\mathrm{H}]^{+} \mathrm{C}_{28} \mathrm{H}_{38} \mathrm{~N}_{3} \mathrm{O}_{2}$, 448.2964). The IR spectrum suggested the presence of $\mathrm{NH}$
(3433 and $3200 \mathrm{~cm}^{-1}$ ) and carbonyl group(s) $\left(1677 \mathrm{~cm}^{-1}\right)$. The ${ }^{1} \mathrm{H}-\mathrm{NMR}$ (Table 1) spectrum recorded in DMSO- $d_{6}$ revealed three methyl groups $\left(\delta_{\mathrm{H}} 0.62,0.87,0.98\right)$, and two exchangeable-proton signals $\left(\delta_{\mathrm{H}} 10.36\right.$ and 8.29). Moreover, three ortho coupled aromatic signals $\left(\delta_{\mathrm{H}} 6.90\right.$ dd, $J=7.3,7.3 \mathrm{~Hz}, 6.94 \mathrm{~d}, J=7.3 \mathrm{~Hz}$ and $7.18 J=7.3 \mathrm{~Hz}$ ) indicated a 1,2,3-trisubstituted benzene ring. The methylene protons $\left(\delta_{\mathrm{H}} 3.23\right)$ coupled with a olefinic proton $\left(\delta_{\mathrm{H}} 5.27\right)$, along with two vinylic methyls $\left(\delta_{\mathrm{H}} 1.67\right.$ and 1.70 ), indicated the presence of a 3-methyl-2-butenyl group in 1. The one-bond connectivities of these protons and another 14 methine and or methylene protons were established by a HMQC experiment. The ${ }^{13} \mathrm{C}-\mathrm{NMR}$ and DEPT (Table 1) spectra, which disclosed 28 signals, also confirmed the presence of these two fragments [trisubstituted benzene ring $\left(\delta_{\mathrm{C}} 123.6 \mathrm{CH}, 120.8 \mathrm{CH}, 127.7\right.$ $\mathrm{CH}, 122.1 \mathrm{qC}$ and $140.4 \mathrm{qC})$ and a 3-methyl-2-butenyl ( $\delta_{\mathrm{C}}$ $28 \mathrm{CH}_{2}, 121.9 \mathrm{CH}, 132.3 \mathrm{qC}, 25.5 \mathrm{CH}_{3}$ and $\left.17.7 \mathrm{CH}_{3}\right)$ ]; in addition, two carbonyls $\left(\delta_{\mathrm{C}} 183.1\right.$ and 172.3), four $s p^{3}$ quaternary carbons $\left(\delta_{\mathrm{C}} 46.5,58.7,60.4\right.$, and 62.3$)$, two $s p^{3}$ methines $\left(\delta_{\mathrm{C}} 46.1\right.$ and 58.7), and six $s p^{3}$ methylenes $\left(\delta_{\mathrm{C}}\right.$ $20.7,31.8,34.3,35.2,39.9$ and 64.9$)$ were also observed. Since 6 out 12 unsaturations were accounted for, 1 was inferred to contain six rings. Further evaluation of these spectral data, along with ${ }^{1} \mathrm{H}-{ }^{1} \mathrm{H}$ COSY and $\mathrm{HMBC}$ results, revealed that $\mathbf{1}$ is closely related to the marcfortine group of fungal metabolites [7]. Interpretation of $\mathrm{HMBC}$ correlations (Fig. 2) indicated the presence of partial structure A (HMBC correlations 1-NH to C-8 and C-9; H-6 to $\mathrm{C}-26$; $\mathrm{H}-5$ to $\mathrm{C}-7$ and $\mathrm{C}-9 ; \mathrm{H}-26$ to $\mathrm{C}-28$ and $\mathrm{C}-8$ and $\mathrm{H}-27$ to $\mathrm{C}-29$ and C-30) and B (HMBC correlations H-10 to $\mathrm{C}-3, \mathrm{C}-22, \mathrm{C}-21, \mathrm{C}-11, \mathrm{C}-12$; $\mathrm{H}-20$ to $\mathrm{C}-13, \mathrm{C}-18, \mathrm{C}-22$, $\mathrm{C}-11$ and $19-\mathrm{NH}$ to $\mathrm{C}-13, \mathrm{C}-10$ ), and $\mathrm{C}$, a six membered $\mathrm{G}$ ring [8] with a methylated carbon at $\mathrm{C}-17$ (HMBC correlations $\mathrm{H}-23$ to $\mathrm{C}-17, \mathrm{C}-16$ ). The connectivity of substructure A to B through C-3 was supported by the key HMBC correlations from $\mathrm{H}-4$ and $1-\mathrm{NH}$ to $\mathrm{C}-3 ; \mathrm{H}-10$ to $\mathrm{C}-2$ and $\mathrm{C}-9$. The connection between structure $\mathrm{B}$ and $\mathrm{C}$ with a nitrogen atom was deduced by the key HMBC correlations from $\mathrm{H}-12$ to $\mathrm{C}-17$ and $\mathrm{C}-13$ and comparing their corresponding chemical shifts of $\mathrm{C}-12$ and $\mathrm{C}-17\left(\delta_{\mathrm{C}}\right.$ 64.9 and 58.7). The above analysis indicated that 1 had a similar structure to marcfortine $\mathbf{A}$ except for the differences of the side chain at benzene ring and a methyl at $\mathrm{C}-17$ of the six membered $G$ ring. So the gross structure of $\mathbf{1}$ was assigned as shown in Fig. 1.

The relative stereochemistry of $\mathbf{1}$ was elucidated on the basis of NOESY data (Fig. 3). Previous studies have revealed that the 2-oxindole alkaloid type compounds adopted a conformation in which the central five-membered ring is orthogonal to the plane of the oxindole subunit [9]. 

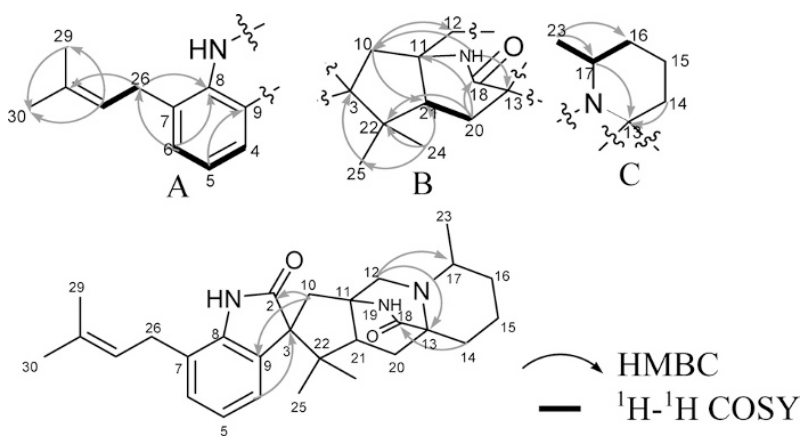

Fig. 2 Key $\mathrm{HMBC}$ and ${ }^{1} \mathrm{H}^{-}{ }^{1} \mathrm{H}$ COSY correlations of $\mathbf{1}$.

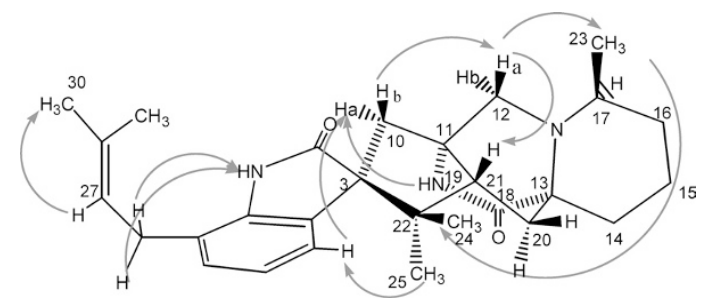

Fig. 3 NOESYS of $\mathbf{1}$

NOESY correlations between H-4 and H-10a, H-25 and between 19-NH and H-10a indicated that they were both on the face of the cyclopentanoid ring that orients them toward $\mathrm{H}-4$, fixing the relative stereochemistry at C-3 as shown. NOESY interactions between H-21, H-12a, H-10b, H-23 and H-24 placed the corresponding substituents together on the frontal face of the cyclopentanoid ring. The relative stereochemistry proposed for $\mathbf{1}$ is in agreement with the relevant features of the relative stereochemistry of marcfortine A [7]. The Cotton effect at 200 250 nm arises from an $n-\pi^{*}$ transition of the diketopiperazine amide bonds, which is diagnostic for the bicyclo-[2.2.2] diazaoctane diketopiperazine core $[10,11]$. The CD spectrum of 1 (Fig. 4) correlated to relevant regions of that of (+)-brevianamide A [11]. So the absolute stereochemistry of 1 should be $3 S, 11 S, 13 S, 17 S, 21 R$ and was given the name of chrysogenamide A.

Preliminary evaluation of the protective effect of chrysogenamide A on neurocytes was evaluated using oxidative stress-induced cell death in SH-SY5Y cells by an MTT assay. The free radical scavenging activity of chrysogenamide A was first examined using DPPH as a free radical donor. In contrast to vitamin $\mathrm{C}\left(\mathrm{IC}_{50}: 29.0 \mu \mathrm{M}\right)$, chrysogenamide $\mathrm{A}$ did not show any ability ( $\mathrm{IC}_{50}$ $>100 \mu \mathrm{M})$ to scavenge DPPH free radical at a concentration up to $100 \mu \mathrm{M}$. Meanwhile we tested whether chrysogenamide A protected cells against oxidative stressinduced cell death in SH-SY5Y human neuroblastoma

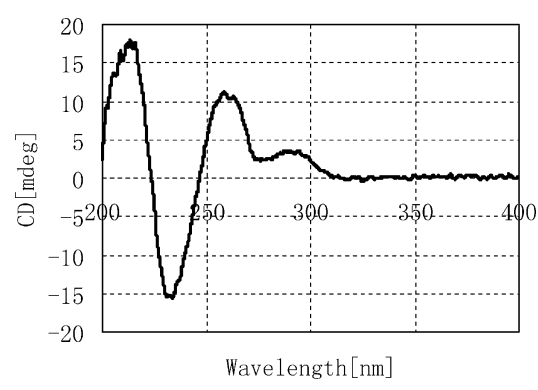

Fig. 4 CD spectrum of $\mathbf{1}$.

cells. The oxidative stress by hydrogen peroxide resulted in a decrease in the cell viability by $43 \%$ as compared with control group. Chrysogenamide A inhibited cell death induced by hydrogen peroxide by improving cells viability by $59.6 \%$ at concentration of $1 \times 10^{-4} \mu \mathrm{M}$. These data suggested that chrysogenamide A showed a neurocyte protection effect against oxidative stress-induced cell death, not through its antioxidant activity.

Indole alkaloids possessing an unusual bicyclo [2.2.2] diazaoctane ring system have been isolated from different genera of fungi such as Aspergillus [12, 9, 13], Penicillium [14 16] and Malbranchea [17]. 1 was a new member of this group of compounds, it possessed a skeleton expected to be an intermediate in the biosynthesis of the citrinadins A and B reported as a novel class of pentacyclic spiroindolinone alkaloids in 2005 [18]. From the structural point of view, it is important to point out that $\mathbf{1}$ is a unique structure with methylation at position $\mathrm{C}-17$ and a 2oxindole moiety possessing an isoprene unit at C-7. Some of these indol alkaloids isolated to date exhibit a potent antiparasitic activity [19], inhibition of human tumor cell [13] and cytotoxicity [10]. To the best of our knowledge, it is the first report of neuroprotection by this type of alkaloids.

Acknowledgment This work was financially supported by the Chinese National Natural Science Fund (No. 30472136).

\section{References}

1. Li LL, Wang XW, Wang XF. Antilipid peroxidation and antiradiative action of glycosides in herba Cistanches. China J Chin Mater Med 22: 364-367 (1997)

2. Xie JH, Wu CF. Effect of ethanolic extract of Cistanche deserticola on the contents of monoamine neurotransmitters in rat brain. Chin Trad Herb Drugs 24: 417-419 (1993)

3. Dai JR, Carte BK, Sidebottom PJ, Yew ALS, Ng SB, Huang Y, Butler MS. Circumdatin G, a new alkaloid from the fungus Aspergillus ochraceus. J Nat Prod 64: 125-126 
(2001)

4. Kettering M, Sterner O, Anke T. Antibiotics in the chemical communication of fungi. Zeitschrift fuer Naturforschung, C: Journal of Biosciences 59: 816-823 (2004)

5. Trifonov LS, Bieri JH, Prewo R, Dreiding AS, Hoesch L, Rast DM. Isolation and structure elucidation of three metabolites from Verticillium intertextum: sorbicillin, dihydrosorbicillin and bisvertinoquinol. Tetrahedron 39: 4243-4256 (1983)

6. Zhang GL, Xing QY, Zhang MZ. Glycolipids from Mirabilis himalaica. Phytochemistry 45: 1213-1215 (1997)

7. Polonsky J, Merrien MA, Prange T, Pascard C, Moreau S. Isolation and structure (X-ray analysis) of marcfortine A, a new alkaloid from Penicillium roqueforti. J C S Chem Comm 13: 601-602 (1980)

8. Lee BH, Kornis GI, Cialdella JI, Clothier MF, Marshall VP, Martin DG, McNally PL, Mizsak SA, Whaley HA, Wiley VH. Microbiological hydroxylation at six individual carbon atoms of marcfortine A. J Nat Prod 60: 1139-1142 (1997)

9. Whyte AC, Gloer JB, Wicklow DT, Dowd PF. Sclerotiamide: A new member of the paraherquamide class with potent antiinsectan activity from the sclerotia of Aspergillus sclerotiorum. J Nat Prod 59: 1093-1095 (1996)

10. Kato H, Yoshida T, Tokue T, Nojiri Y, Hirota H, Ohta T, Williams RM, Tsukamoto S. Notoamides A D: prenylated indole alkaloids isolated from a marine-derived fungus, Aspergillus sp. Angew Chem Int Ed 46: 2254-2256 (2007)

11. Williams RM, Kwast E, Coffman H, Glinka T. Remarkable, enantio-divergent biogenesis of brevianamide A and B. J Am Chem Soc 111: 3064-3065 (1989)

12. Banks RM, Blanchflower SE, Everett JR, Manger BR,
Reading C. Novel anthelmintic metabolites from an Aspergillus species: the aspergillimides. J Antibiot 50: 840-846 (1997)

13. Qian-Cutrone J, Haung S, Shu YZ, Vyas D, Fairchild C, Menendez A, Krampitz K, Dalterio R, Klohr SE, Gao Q. J Am Chem Soc 124: 14556-14557 (2002)

14. Wilson BJ, Yang DTC, Harris TM. Production, isolation, and preliminary toxicity studies of brevianamide A from cultures of Penicillium Viridicatum. Appl Microbiol 26: 633-635 (1973)

15. Birch AJ, Russell RA. Studies in relation to biosynthesiss XLIV. Structural elucidations of brevianamides B, C, D and F. Tetrahedron 28: 2999-3008 (1972)

16. Liesch JM, Wichmann CF. Novel antinematodal and antiparasitic agents from Penicillium charlesii. II. Structure determination of paraherquamides B, C, D, E, F, and G. J Antibiot 43: 1380-1386 (1990)

17. Martinez-Luis S, Rodriguez R, Acevedo L, Gonzalez MC, Lira-Rocha A, Mata R. Malbrancheamide, a new calmodulin inhibitor from the fungus Malbranchea aurantiaca. Tetrahedron 62: 1817-1822 (2006)

18. Mugishima T, Tsuda M, Kasa Y, Ishiyama H, Fukushi E, Kawabata J, Watanabe M, Akao K, Kobayashi J. Absolute stereochemistry of citrinadins A and B from marine-derived fungus. J Org Chem 70: 9430-9435 (2005)

19. Lopez-Gresa MP, Gonzalez MC, Ciavatta L, Ayala I, Moya P, Primo J. Insecticidal activity of paraherquamides, paraherquamides, including paraherquamide $\mathrm{H}$ and paraherquamide I, Two New Alkaloids Isolated from Penicillium cluniae. J Agric Food Chem 54: 2921-2925 (2006) 